\title{
Call-and-response in The Bluest Eye
}

\author{
Hong $\mathrm{Wu}$ \\ Sichuan Agricultural University, Chengdu, China \\ Liping Yang \\ Sichuan Agricultural University, Chengdu, China
}

\begin{abstract}
Call-and-response is one of African oral traditions. Morrison's use of call-and-response in The Bluest Eye composes the linguistic facet in community conversations and gossips, and the symbolic facet. The symbolic facet of call-and-response accentuates the teller-listener interaction. Toni Morrison hopes that the reader can participate in the text to read beyond the signs in the text to hear the voices and ideologies embedded in the signs. The analysis of the call-and-response in The Bluest Eye shows that Morrison calls the reader to testify to the difficulties the blacks of low economical status has experienced and calls the reader to shed their sympathy onto them.
\end{abstract}

Index Terms - call-and-response, Morison, oral tradition, linguistic facet and symbolic facet

\section{INTRODUCTION}

The Bluest Eye, published in 1969, is the first book of Toni Morison. She explores in The Bluest Eye a working-class urban black family during the 1930s and 1940s in Lorain, Ohio where cultural assimilation through school primers, movies, and almost every other cultural item from cups to candies shows "the violence of Sameness" (Khayati) ${ }^{1}$. The novel focuses on the disintegration of this family, and particularly on the plight of a young black girl named Pecola Breedlove. Growing up in the midst of a white-dominated culture which inflicts devastating impact on the psyche of black people, Pecola is despised, neglected and bullied by people surrounding her for she is black and ugly. She is eventually driven mad after being raped by her father, Cholly, and delivers a dead baby. Her longing for a pair of blue eyes as beautiful as Shirley Temple's is brutally fulfilled in her insanity. As the first-person narrator, Claudia declares in the prologue it is difficult to handle why the tragedy occurs and "one must take refuge in how", Toni Morrison endeavors in how to narrate this story, how to present the reader a global picture of the life of a typical black community which splits into fragments due to the impact of racism.

It is obvious that the unusual employment of narrative devices in The Bluest Eye brings the wide dimensions to the thematic tones of the story and invested the story with great pathos. The uniqueness of its writing techniques reaped its recognition at its debut edition. Houston Chronicle highly praised this thin book with such a comment- "Bold new writing and a sense of timelessness that is the mark of great literature." This "bold new writing" remains blatant and important in her ensuing works as observed by Philip Page:

The narration is frequently subdivided among multiple points of view. So that each novel, while retaining its unity, also projects a collection of perspectives. Plots tend to be circular or spiral rather than linear, as meaning is accreted through repetition and layering and as multiple times are overlaid on each other. By requiring the reader to engage actively, the novels create a plurality-in-unity between reader, text, characters, narrators, and author (1995, p. 4).

Houston Chronicle's praise, on the one hand, acknowledged the importance and brilliance of narrative techniques in The Bluest Eye, on the other, betrayed their unfamiliarity with the African-American oral tradition, which is exactly used by Toni Morrison as narrative techniques, which virtually has a long history in African-American narrative.

Since her childhood, with both parents telling stories and a grandmother playing numbers, Morrison has learnt to appreciate the African American oral tradition and cultural practices. Morrison herself says: I try to incorporate into that traditional genre, the novel, unorthodox novelistic characteristics - so that it is in my view Black, because it uses the characteristics of Black art. I am not suggesting that some of these devices have been used before and elsewhere-—only the reason why I employ them as well as I can (Morrison, 1984, p. 342). Morrison's reconceptualization of the novel seeks to incorporate precisely the elements belonging to the oral tradition of African Americans that have been excluded from or repressed in this traditional genre.

Call-and-response, stemming from the West African ethnic communities, is one of surviving oral elements brought to America by the African slaves. Toni Morrison employs it in The Bluest Eye in both linguistic and symbolic manner. In linguistic manner, Toni Morrison shows its feature in the black speeches; in symbolic manner, Morrison employs this oral element to achieve such narrative goal termed by Page as the "plurality-in-unity between reader, text, characters, narrators, and author."

\footnotetext{
1 See in the web article "Representation, race, and the 'language' of the ineffable in Toni Morrison's narrative" by Abdellatif Khayati. Website: http:// www.findarticles.com/p/articles/mi_m2838.
} 
Trudier Harris in Fiction and Folklore states that Morrison allows no dichotomy between form and substance, theme and character in her employment of black folklore (1991, p. 8). The application of call-and-response in The Bluest Eye conveys Morrison's political view of the cultural, ideological and social values of both African Americans and Americans. Simultaneously she calls the reader to respond to her, either agrees or disagrees with her. Hence, the core of this thesis is to explore how Morrison incorporates call-and-response into The Bluest Eye to obtain political and aesthetic appeal.

\section{MorRison AND THE TRADITION OF CALL-AND-RESPONSE}

The African American oral tradition is the lifeblood of its culture. Black oral expressions comprise many categories or types of folk expressions and Black speech discourse. Among the oral types of expressiveness are: Blues; jazz; spirituals; sermons; toasts; the dozens; cautionary tales; trickster tales; legends; memorates; rural and urban speech patterns; folk beliefs such as voodoo, conjure, and "superstition"; and folk characters as Brier Rabbit, Stagolle, John Henry, the Loup garou, flying African, the conjure woman, the good-time woman, and the aunt ( Byerman , 1985, p. 2).

The oral tradition influences almost all African American literature. It enters the early literature, such as Frederick Douglass's slave narrative. Charles Waddell Chestnut's The Conjure Woman takes its structure from a tale telling tradition of the black community. Perhaps Langston Hughes could be considered to be at the peak of early folk influence upon literary creation. He intimated the structure and sentiments in his poetry. Zora Neale Hurston has always been identified with black folk traditions in her works such as Jonah's Gourd Vine, Their Eyes were Watching God, and Mule and Man. In the oral tradition, African-American novelists have found out a properly idiosyncratic structure and language to construct their views of human existential conditions through the "time-specific, place-specific and race-specific prism" (Gates, 1987, p. 26).

Madhu Dubey in Black Women Novelists and the National Aesthetic suggests that Black women authors of the "second renaissance of the 1970s" affirm oral folk material and culture in their works within the context of Black aestheticism (1994, p. 2). Dubey states that the critical balance (and, at times, ambivalence) with which 1970s Black women novelists approach fold forms is even more clearly visible in their representations of community. Many of the celebratory readings of folk material in Black women's fiction follow Black Aesthetic theory in suggestion that the use of oral forms enables these novels not only to affirm a communal vision but also to establish a continuous and participatory relationship with their readers $(1994$, p. 7). She shows that a literary explosion of Black women writers was influenced by the Black power movement of the 1960s.

Another linguist, Geneva Simitherman, approaches the oral tradition of black vernacular speakers in her text, Talkin and Testifyin in a distinct and empirically useful manner. Smitherman foregrounds the oral tradition of Black American speech into four Black modes of discourse: "call-response; signification...tonal semantics [and] narrative sequencing" (1985, p. 103). She asserts that these Black modes discourse are found "in Black people's common linguistic and cultural history" and that they emanate from "West African language background; servitude and oppression; music and 'cool talk'; traditional Black church"' (1985, p. 43).

Morrison comes of age as a writer drafting The Bluest Eye from 1965 to 1969 . This means that she is squarely in the period of the "black is beautiful" movement (as Morrison herself has noted in the afterword of the Plume paperback edition of The Bluest Eye) that called on African Americans to rethink their relation to white culture and the 1960s' Black Aesthetic movement that called for a distinctively black voice and a black nationalist identity. This social and historical context strongly supports the argument that Toni Morrison appropriates the oral tradition in The Bluest Eye which her ancestors used in their literary creation. This essay focuses on the use of call-and-response.

Call-and-response is one of most popularly used oral devices in the Black community. It developed in slavery as one slave organized the energies of others by issuing a verbal call to which the rest might respond. Geneva Smitherman defines it as an African-derived communication process of "spontaneous verbal and non-verbal interaction between speaker and listener in which all of the speaker's statements ('calls') are punctuated by expressions ('response') from the listener" (1985, p. 104).

Call-and-response provides the basic rhythm for much African music, in gospel singing, blues, rap and jazz. ${ }^{2}$ This $^{\text {a }}$ age-old tradition can be witnessed equally in church related settings. It is primarily a participatory act whereby both the speaker and the listener engage in unifying verbal exchange. The speaker begins (calls out) the usually improvised message, and the listener answers (responds) to the message. Somin Sunkule and Okumba Miruka similary define antiphony as the "Call-and-response pattern of songs in most African songs, [i.e.,] Solo (call)-Chorus (response)" Verbal interaction between the performer (or speaker) and the audience is a noteworthy characteristic of the call-and-response pattern. "In traditional Black church services, the preacher depends on the expressed reactions of the congregations to judge the direction and success of his sermon" (Byerman, 1985, p. 7). Lack of response means that the person is not recognized or accepted as a leader. Response gives a leader a suggestion for the direction his or her next call might take.

In the Civil Rights Movement, one of the most famous speeches exemplifies call-and-response. In "I have a dream",

\footnotetext{
2 the following line picked from a song applies call-and-response:

| ---------Call--------- | ----Response-- |

Fare-well fel-low sarvants! O-ho! O-ho!
} 
Martin Luther King, a black minister, issued a call to respond the previous one made by another minister. Since then King's call in "I Have a Dream" has received many thousand responses as Americans of all races pay tribute to his ideas (Kubitschek, 1998, p. 101). Likewise, in secular settings, such as in the barber shop and beauty house, the antiphonal exchange occurs in the Black conversations when a speaker initiates the communicative process and an individual or group interactively responds to the speaker. The participants of the speech act are equally important in reaffirming each other as integral parts of a unified speech process (Young 4).

\section{CALL-AND-RESPONSE IN A LINGUISTIC MANNER}

Morrison specifically honors call-and-response. She regards call-and-response as vital to Black community life. Toni Morrison adopts call-and-response in a linguistic manner which involves the interactive and reciprocal process between a speaker and his/her listener. The speaker presents his or her message and receives a spontaneous reciprocal response from his/her audience or one speaker affirms or agrees with another.

As Michael Awkward has stated, "the pattern [call-and-response] 'permeates' the Afro-American vernacular community and reaffirms Black culture's insistence on interactive unity" (1991, p. 49). The traditional use of call-and-response is evident in the chatting among black women in the community where Pecola, Claudia, and Frieda inhabit.

The example of call-and-response appears in the conversation between the unidentified women who attend Aunt Jimmy's funeral ceremony. In this conversation one woman inquires the death cause of Aunt Jimmy; the woman who possesses the information responds briefly with two words "Essies' pie", which arouses the curiosity of the woman in the dark, she further responds to this answer with a question "Don't say". Then, the conversation goes smoothly with one woman presenting her message and receiving the spontaneous response from the other who initiates the question or agrees, and the large amount of information about the death of Aunt Jimmy is channeled to the listener.

"What she die from?"

"Essie's pie."

"Don't say?"

"Uh-huh. She was doing fine, I saw her the very day before. Said she wanted to bring her some black thread to patch some thing for the boy. I should of known just from her wanting black thread that was a sign."

"Sure was."

"Just like Emma. 'Member? She kept asking for thread. Dropped dead that very evening."

"Yeah. Well, she was determined to have it. Kept on reminding me. I told her I had some to home, but naw, she wanted it new. So I sent Li'l June to get some that very morning when she was laying dead. I was just fixing to bring it over, 'long with a piece of sweet bread. You know how she craved my sweet bread."

"Sure did. Always bragged on it. She was a good friend to you."

"I believe it. Well, I had no more got my clothes on when Sally bust in the door hollering about how Cholly here had been over to Miss Alice saying she was dead. You could have knocked me over, I tell you."

"Guess Essie feels might bad."

"Oh, Lord, yes. But I told her the Lord giveth and the Lord taketh away. Wasn't her fault none. She makes good peach pies. But she bound to believe it was the pie did it, and I "spect she right."

[...] (Morrison, 1970, p. 110).

Morrison herself comments on call-and-response feature of the black conversations in an interview. She says: " In order to get a real response because that's the other aspect, they [black speakers] do not expect you to listen silently, in a sort of western tradition; you've supposed to tap your feet or say 'Amen' or jump up to dance or say what have you. But there is this connection orator and listener." The women in the above conversation are aware of this trait of Black conversation (1984, p. 341). They exert themselves in their due role: the speaker informs and the listener responds actively. With the full cooperation of the speaker and the listener, the conversation gathers much momentum and goes further and further. It is this charm of "the creamy [black] conversations" that "fascinated" Cholly as well as the reader.

Call-and-response enacts in another scene between two prostitutes. In this sequence, China initiates the sequence by asking a question of Poland. Poland answers and China affirms her response with a "me too." Then the laughter between the prostitutes affirms even more the social and oral interaction between the women:

China arranged a fingerful of hair into a bang of effect.

"Then why he left you to sell tail?'

"Girl, when I found out I could sell it somebody would pay cold cash for it, you could have kocked me over with a feather."

Poland began to laugh. Soundlessly.

"Me too. My auntie whipped me good that first time when I told her I didn't get no money. I said 'money? For what" he didn't owe me nothin'."

She said, 'The hell he didn't!"

They all dissolved in laughter (Morrison, 1970, p. 42).

China in this sequence recounts to her pals how she initially entered the profession. Poland concurs with China and reveals her aunt's anger for her engaging in a "freeby." This episode ends with all three of the prostitutes laughing. The 
verbal comments between China and Poland show a call-and-response pattern of shared interaction and a unified connection between the prostitutes. One speaks and the other agrees in confirmation with the third. Ultimately they all laugh together to reveal a shared harmony among them (Young 58).

\section{CALL-AND-RESPONSE: THE INTERACTION BETWEEN THE READER AND THE AUTHOR}

In her renowned essay, "Rootedness: The Ancestors as Foundation," Morrison asserts that there are things that I try to incorporate into my fiction that are directly and deliberately related to what I regard as Black art, wherever it is. One of which is the ability to be both print and oral literature: to combine those two aspects so that the stories can be read in silence, of course, but one should be able to hear them as well. [...] In the same way that a musician's music is enhanced when there is a response from the audience... to have the reader work with the author in the construction of the book -- is what's important. [...] To construct the dialogue so that it is heard. (1984, p. 341)

She compares this participatory relationship to a Black preacher who requires his church congregation to interact with him and "to join him in the sermon, to behave in a certain way, to stand up and to weep and to cry and to accede or to change and to modify - to expand the sermon that is being delivered" (1984, p. 341).

Morrison emphasizes the need for the reader to understand her language whether "speakerly, aural, colloquial". She describes her own work as containing "holes and spaces so the reader can come into it" (qtd. Tate, 1985, p. 125), testament to her rejection of theories that privilege the author over the reader. Morrison distains such hierarchies in which the reader as participant in the text is ignored: "My writing expects, demands participatory reading, and I think that is what literature is supposed to do. It's not just about telling the story; it's about involving the reader... we (you, the reader, and I, the author) come together to make this book, to feel this experience" (qtd. Tate, 1985, p. 125). Call-and-response in The Bluest Eye reveals a pattern that "evolves into a resilient literary device that persuades readers to become symbolic and then perhaps actual participants into the task of image-making, of storytelling" In this context call-and-response engages the writer and reader in a human situation analogous to that of performer and audience (Callahan, 2001, p. 17).

One passage illustrates quite clearly call-and-response as an active participatory relationship between the writer-narrator and reader. It occurs between Blacks of two different socio-economic classes, which are distinguishable by their funkiness. Geraldine of the middle class is anti-funk, whereas Pecola is the essence of funk. Morrison characterizes Geraldine as one of the many brown girls in the middle class who live in quiet Black neighborhood where everybody is gainfully employed. Where there are porch swings handing from chains [...] they go to land-grant colleges, normal schools, and learn how to do the white man's work with refinement...Here they learn the rest of the lesson begun in those soft houses with porch swings and pots of bleeding heart: how to behave. The careful development of thrift, patience, high morals, and good manners. In short, how to get rid of funkiness. The dreadful funkiness of passion, the funkiness of nature, the funkiness of the wide range of human emotions (Morrison, 1970, p. 64).

The key point of these women's inauthentic behavior is their repression of all human nature and emotions. Geraldine, who has contained her funkiness and who has endeavored to teach her son to imitate the white middle-class, is contrasted with Pecola. Morrison, however, pricks the audience/reader's emotions to go even further in the emerging process. Through the omniscient narrator, she calls on the audience/reader to respond emotionally to the ill-treatment imposed on pitiable Pecola.

Junior, the middle-class son of Geraldine, invites Pecola to his home near their school on the pretense of showing her some kittens. Pecola hesitantly decides to go. The audience/reader senses some foreboding dread about to come to Pecola in her youthful innocence. Once inside the lovely well-furnished home, Pecola is awed by its interior with the big lamps and rugs on the floor. She savors everything by looking slowly at the beautiful furnishings (Morrison, 1970, p. 70). Junior, a sadistic child who really dislikes his mother's cat and his mother too, sees Pecola's interest in his mother's house and her cat and decidedly taunts and beats up Pecola. Then he "pushes her down, ran out the door... and held it shut with his hands. Pecola's banging on the door increased his gasping, high-pitched laughter" (Morrison, 1970, p. 70). Locked in the room, Pecola begins to cry until the soft wounded kitten comforts her and she it. Seeing Pecola comfort the cat, Junior gets angry, for he "had seen that expression many times as the animal responded to his mother's touch" (Morrison, 1970, p. 71). He grabs the cat and in a frenzied moment throws the cat against the window. The cat falls onto the radiator with only "the slightest smell of singed fur" (Morrison, 1970, p. 71).

At this point Junior's behaviors provokes the reader to ask how a young boy could be so evil. The young boy is himself an extreme case of the schizophrenic double consciousness. On the one hand, he wants to play with the other children, get dirty, and laugh. On the other hand, his mother, Geraldine, had taught him not to play with "niggers," and had explained the difference between the colored people and the niggers: "Colored people were neat and quiet; niggers were dirty and loud" " (Morrison, 1970, p. 67). Although Junior knew the difference between the two groups, he wanted to play with black boys, "he wanted to feel their hardness pressing on him, smell their wild Blackness, and say 'Fuck you' with that lovely casualness. He wanted to sit with them on curbstones and compare the sharpness of jackknives, the distance and arcs of spitting" (Morrison, 1970, p. 68). Instead of enjoying the casual, fun life of active black boys, he bullies girls, who cannot physically return his aggression.

When one observes Geraldine and Maureen attacking Pecola, one conjures up images who, under the influence of white racism, believe that they are superior to other dark-skinned niggers according to the spectrum. Morrison, in the 
form of Claudia or the omniscient narrator, calls readers to respond to these scenes with Pecola and to censure these types of Black people for their selfishness, mean spiritedness, and inhumanity to other Blacks. Call-and-response enables the reader to read beyond the signs in the text to hear the voices and ideologies embedded within those signs. It elicits from the reader a political response and emotional response, as Morrison states, "the work must be political" (1984, p. 342).

Junior's mother, Geraldine, also exhibits a condescending attitude toward Pecola's Blackness. When Junior's mother enters the room, she sees the "funkiness" of Pecola and the deplorable images of her kind and immediately charges into her repugnantly:

She looked at Pecola. Saw the dirty torn dress, the plaits sticking out on her head, hair matted where the plaits had come undone, the muddy shoes with the was of jam peeping out from which had been walked down into the heel of the shoe. She saw the safety pin holding the hem of the dress up. Up over the hump of the cat's back she looked at her. She had seen this little girl all of her life. Hanging out of windows over saloons in Mobile, crawling over the porches of shotgun houses....Hair uncombed, dresses falling apart, shoes untied and caked with dirt (Morrison, 1970, p. 71).

Geraldine doesn't see an individual, but a class of people, the class she and others of her kind deplore. "They were everywhere....like flies they hovered; like flies they settled. And this one had settled in her home. Up over the hump of the cat's back she looked" (Morrison, 1970, p. 72). In a controlled manner, quite representative of her class, Geraldine says, "Get out...You nasty little Black bitch. Get out of my home" (Morrison, 1970, p. 72). The reader observes Pecola's reaction:

Pecola backed out of the room, staring at the pretty milk-brown lady in the pretty gold-and-green house who was tailing to her through the cat's fur... Pecola turned to find the front door and saw Jesus looking down at hr with sad and unsurprised eyes... the gay paper flowers twisted his face.

Outside, the March wind blew into the rip of her dress. She held her head down against the cold. But she could not hold it low enough to avoid seeing the snowflakes falling and dying on the pavement (Morrison, 1970, p. 72).

In this moving, dramatic scene, Morrison is politically calling the reader to respond to mistreatment of Pecola. Not only Geraldine insists that the ragged child leave, but she calls the child horrid epithets: "nasty, Black bitch." The reader in recoiling from such disparaging language responds with aversion, extreme distaste, and maybe even horror. Adeptly Morrison does not permit the reader to explore the feeling of pathetic Pecola. Much space is left for the reader to respond to Pecola who appears so small and vulnerable in the snow-falling background, the symbol of hostile condition. In this sense, what is left unsaid is equally as important as what is stated and specified; what is felt is as significant as what is experienced (Rigney, 1991, p. 26).

One notices also Pecola's response - her backing out of the room is reminiscent of a servant leaving a room filled with royalty. Added to this scenario is Pecola's seeing "Jesus looking down at her with sad and unsurprised eyes", again conjuring up images of a pathetic child looking up to Jesus and Jesus reciprocally responding to her plight.

Other passages in The Bluest Eye point to Morrison's appropriation of call-and-response. Again Morrison's use of call-and-response occurs between the narrator and the reader-where the narrator admonishes the reader to respond to her call. Maureen Peal, the new light-skinned girl who is liked by most of the students and teachers alike. She initially appears to befriend Pecola by buying an ice cream cone. The reader learns quite soon, however, that Maureen has an ulterior motive. When Maureen wants to talk of Pecola's "naked daddy" and Pecola does not return her insult.

Pecola then "tucked her head in -in a funny, sad, helpless movement. A kind of hunching of the shoulders, pulling in of the neck as though she wanted to cover her eye" (Morrison, 1970, p. 56). Claudia comes to the defense of Pecola, but Maureen recoils with harsh epithets to all three girls reminiscent of Geraldine: "Black and ugly blacker e mos" and she adds that she was cut (Morrison, 1970, p. 56). The reader realizes that Maureen's insults have hurt Pecola the most. But she is maimed and fails to respond. Thus Claudia as the storyteller calls the reader-audience to respond to this situation symbolically and aurally:

Pecola stood a little apart from us, her eyes hinged in the direction in which Maureen had fled. She seemed to fold into herself, like a pleated wing. Her pain antagonized me. I wanted to open her up, crisp her edges, ram a stick down that punched and curving spine, force her to stand erect and spit the misery out on the street. But she held it in [...]. (Morrison, 1970, p.57)

The cast of Pecola's image has been set. Callahan notes that "symbolically present in the literary genre of fiction, these variations of call-and-response summon us to read and hear, and potentially contribute to the still unfolding 'immense story' in our lives and voices beyond the solitary, private act of reading "(2001, p. 21). The reader is expected to respond to the experience in the story of The Bluest Eye and possibly to politicize the scenes or story of Pecola's life. Through call-and-response, Toni Morrison calls the reader to testify to the difficulties the blacks of low economical status has experienced and calls the reader to shed their sympathy onto them. Call-and-response brings the reader to come to terms with Morrison's political and emotional attempts.

Morrison has admitted that she does not mind taking risks and that she enjoys " the danger in writing when you're right on the edge, when at any moment you can be maudlin, saccharine, grotesque, but somehow pull back from it, well, most of the time"'(qtd. in Rigney, 1991, p. 6). This is the emotional response she expects the reader to experience. In addition to it, she wants an "intellectual response to the complex ideas" in her work. By using call-and-response, Morrison achieves these goals and fulfills her responsibility "to do both at the same time" since "that's what a real story 
is" (Rigney, 1991, p. 6).

\section{CONCLUSION}

Barbara Hill Rigney observes, Morrison "scatters her signs, her political insights," thus demanding rigorous analyses of her "language" for readers, who are willing to "reconstruct an idea of the political and artistic revolution constituted in her work" (1991, p.7). Morrison herself variously describes the ideal reader of her fiction as herself, the characters in her novels, or the black "village". The application of call-and-response in The Bluest Eye, her first novel, demonstrates this writing philosophy. Call-and-response invites the reader to rework the traumas and dilemmas the Blacks have endured. Thus call-and-response acquires "the power to expand the souls of all readers" (Page, 1995, p. 187). Sympathy for the pathetic characters and accusation of the culprit, racism, is what Morrison intends to elicit from the reader. Due to the employment of call-and-response, The Bluest Eye appears no longer a solitary text but a dialogic one completed with the reader and the author's collaborative enterprise.

\section{REFERENCES}

[1] Awkward, Michael. (1991). Inspiring influences: Tradition, revision, and Afro-American women's novels. New York: Columbia University Press.

[2] Byerman, Keith E. (1985). Fingering the jagged grain: tradition and form in recent black fiction. Athens: University of Georgia press.

[3] Callahan, ByJohn F. (2001). In the African-American grain: Call-and-response in twentieth-century black fiction. Urbana: University of Illinois Press.

[4] Dubey, Madhu. (1994). Black women novelists and the national aesthetic. Bloomington: Indiana University Press.

[5] Gates, Henry Louise, Jr. (1998). The signifying monkey: A theory of Afro-American literary criticism. New York: Oxford University Press.

[6] Gates, Henry Louise, Jr. (1987). Figures in Black - Words, signs, and the "racial" self. New York: Oxford University Press.

[7] Harris, Trudier. (1991). Fiction and folklore: The novels of Toni Morrison. Knoxville: University of Tennessee Press.

[8] Kubitschek, Missy Dehn. (1998). Toni Morrison: A critical companion. Westport: Greenwood Press.

[9] Morrison, Toni. (1984). Rootedness: The ancestor as foundation." In Marie Evans (ed.), Black women writers (1950-1980): A critical evaluation. New York: Anchor.

[10] Morrison, Toni. (1970). The bluest eye. New York: Washington Square Press, 1970.

[11] Page, Philip. (1995). Dangerous freedom: Fusion and fragmentation in Toni Morrison's Novels. Jackson: University Press of Mississippi.

[12] Rigney, Barbara Hill. (1991). The voices of Toni Morrison. Columbus: Ohio State University Press.

[13] Smitherman, Geneva. (1985). Talkin and testifyin: The language of black America. Detroit: Wayne State UP.

[14] Tate, Claudia. (ed.) (1985). Black women writers at work. New York: Continuum.

[15] Young, Eliza Marcella. (no date). The African American oral tradition in selected writings of Zora Neale Hurston, Toni Morrison and Alice Walker. http://www.Proquest.calis.edu.cn/uni/detail-usmark.jsp (accessed 17/1/2012).

Hong Wu, born in 1975, Sichuan province, China, is currently a lecturer of English at Sichuan Agricultural University, Chengdu, China. She earned her master's degree in English Language and Literature from Sichuan Normal University, China, in 2006. Her research interests cover such areas as contemporary American literature, and esp., African American literature.

Liping Yang, born in 1976, Sichuan province, China, is currently a lecturer of English at Sichuan Agricultural University, Chengdu, China. Her research interests are American literature and English teaching methodology. 